\title{
Smallholder Pigs Production Systems in Tanzania
}

\author{
Eliakunda Kimbi ${ }^{1}$, Faustin Lekule ${ }^{2}$, James Mlangwa ${ }^{3}$, Helena Mejer ${ }^{4}$ and Stig Thamsborg ${ }^{4}$ \\ 1. Tanzania Livestock Research Institute (TALIRI), Uyole, P.O. Box 6191, Mbeya 53126, Tanzania
}

2. Department of Animal Science and Production, Sokoine University of Agriculture, P.O. Box 3004, Morogoro 67125, Tanzania

3. Department of Veterinary Medicine and Public Health, Sokoine University of Agriculture, P.O. Box 3021, Morogoro 67125, Tanzania

4. Department of Veterinary Disease Biology, Faculty of Health and Medical Sciences, University of Copenhagen, Dyrlaegevej 100, DK-1870 Frederiksberg C, Denmark

\begin{abstract}
Pig production is becoming increasingly important in Eastern Africa in recent years. Two studies were carried out in Mbozi and Mbeya rural districts to characterise smallholder pig production systems and associated pig management practises. A participatory rural appraisal (PRA), involving 279 pigs-keeping households in nine villages and a cross sectional survey using a random sample of 300 pig farmers in 30 villages of the study districts, were used to collect data. Important economic activities were crop farming, livestock keeping, petty business, casual labour and artisan works in that order. The mean farm size and number of pigs per household was $2 \pm 2.7$ ha and $4.9 \pm 4.2$ pigs, respectively. The largest categories of pig herd structure were breeding females followed by piglets. Age, marital status, household size and land size of household head had significant influence on the pig herd size $(P<0.05)$. Pig farmers practised three main types of pig management systems, namely, total confinement, semi confinement and free range/herding. Each system had specific management practices in relation to feeding and housing. The frequencies of these systems varied significantly $(P<0.01)$ by socio-economic factors, such as, educational status of household head, land size and herd sizes of pigs, goats and cattle. The authors recommend effective use of locally available resources and careful consideration of existing farming systems for sustainable development of smallholder pig production.
\end{abstract}

Key words: Smallholder, pig management, systems and practices.

\section{Introduction}

Tanzania is an agrarian country, with which about $80 \%$ of its labour force are engaged in agriculture production and over $80 \%$ of its population lives in rural areas dependent on mainly crop and livestock enterprises to support their livelihoods [1]. Out of the 5.8 million agricultural households in Tanzania, about $40 \%$ are keeping livestock. Cattle, goats and poultry are traditionally the major livestock kept. However, in the last two decades, pig production has shown remarkable growth in terms of pig population, pork production and consumption [2-4]. Similar developments have been observed in other parts of Eastern and Southern Africa (ESA) countries [5-7]

Corresponding author: Eliakunda Kimbi, Ph.D., research fields: smallholder farmers and livestock production systems. E-mail: cekimbi@yahoo.com. and Asia [8-12].

Pig farming in Tanzania is mainly carried out by smallholder farmers, involving over 500,000 rural households, representing about $22.4 \%$ of agricultural households [3]. Most pigs are kept in high altitude areas, where the human population density is high and the land is of high agricultural potential. About 54\% of the pigs in the country are thus found in the Southern highlands of Tanzania (SHT) regions (Mbeya, Iringa, Rukwa and Ruvuma) [3]. In these areas, smallholder pig farming plays an important role in securing livelihoods of rural communities and availability of meat to rural and urban areas. Similar roles of smallholder pig farming has also been reported in other ESA countries [6, 13-15], and other developing countries such as India [11], Vietnam [10] and China $[16,12]$. 
Pig production in most areas of Tanzania are dominated by traditional production systems and practices, characterized by small herds, low level of biosecurity and productivity, low market off takes and poor food safety, which pose substantial limitations on the public health and economic viability of smallholder farmers and general public. Improvements are greatly needed, but basic information on the characteristics of smallholder pig production systems, which is the prime key for developing the sector, has so far been inadequate. The present study aimed at characterising smallholder pig production in Tanzania and identifying key issues and opportunities for improvement.

\section{Materials and Methods}

\subsection{Study Area}

The study was conducted in Mbozi and Mbeya rural districts situated in Mbeya region in the Southern highlands of Tanzania. Mbozi district is located in the South-Western corner of Mbeya region at altitudes between $900 \mathrm{~m}$ and $2,750 \mathrm{~m}$ above main sea level. It lies between latitudes $8^{\circ} 14^{\prime} \mathrm{S}$ and $9^{\circ} 24^{\prime} \mathrm{S}$ and longitudes $32^{\circ} 04^{\prime} \mathrm{E}$ and $33^{\circ} 13^{\prime} \mathrm{E}$. The district comprises 184 villages, covering a total of $9,586 \mathrm{~km}^{2}$ with a human population of 643,157 inhabitants [17]. Mbeya rural district lies between latitudes $8^{\circ} 38^{\prime} \mathrm{S}$ and $9^{\circ} 20^{\prime} \mathrm{S}$ and longitudes $33^{\circ} 01^{\prime} \mathrm{E}$ and $33^{\circ} 49^{\prime} \mathrm{E}$ at altitudes between $1,000 \mathrm{~m}$ to $2,400 \mathrm{~m}$ above main see level. It has 126 villages covering a total area of 2,334 $\mathrm{km}^{2}$ with 305,319 inhabitants [17]. The randomly selected study villages in both districts are shown in Fig. 1.

\subsection{Study Designs}

\subsubsection{Participatory Rural Appraisal (PRA)}

The PRA survey design was employed to collect qualitative data for characterizing the smallholder pig production environment in the context of a farming systems approach $[18,19]$. Four villages from Mbeya rural and five from Mbozi districts were randomly selected from the 30 villages sampled in the cross-sectional study after stratification for agro-ecological zones (AEZ) in each district [20]. In Mbeya rural, Mjele, Igoma, Horongo and Jojo villages were sampled from AEZ 7C: Rukwa-Songwe valley,

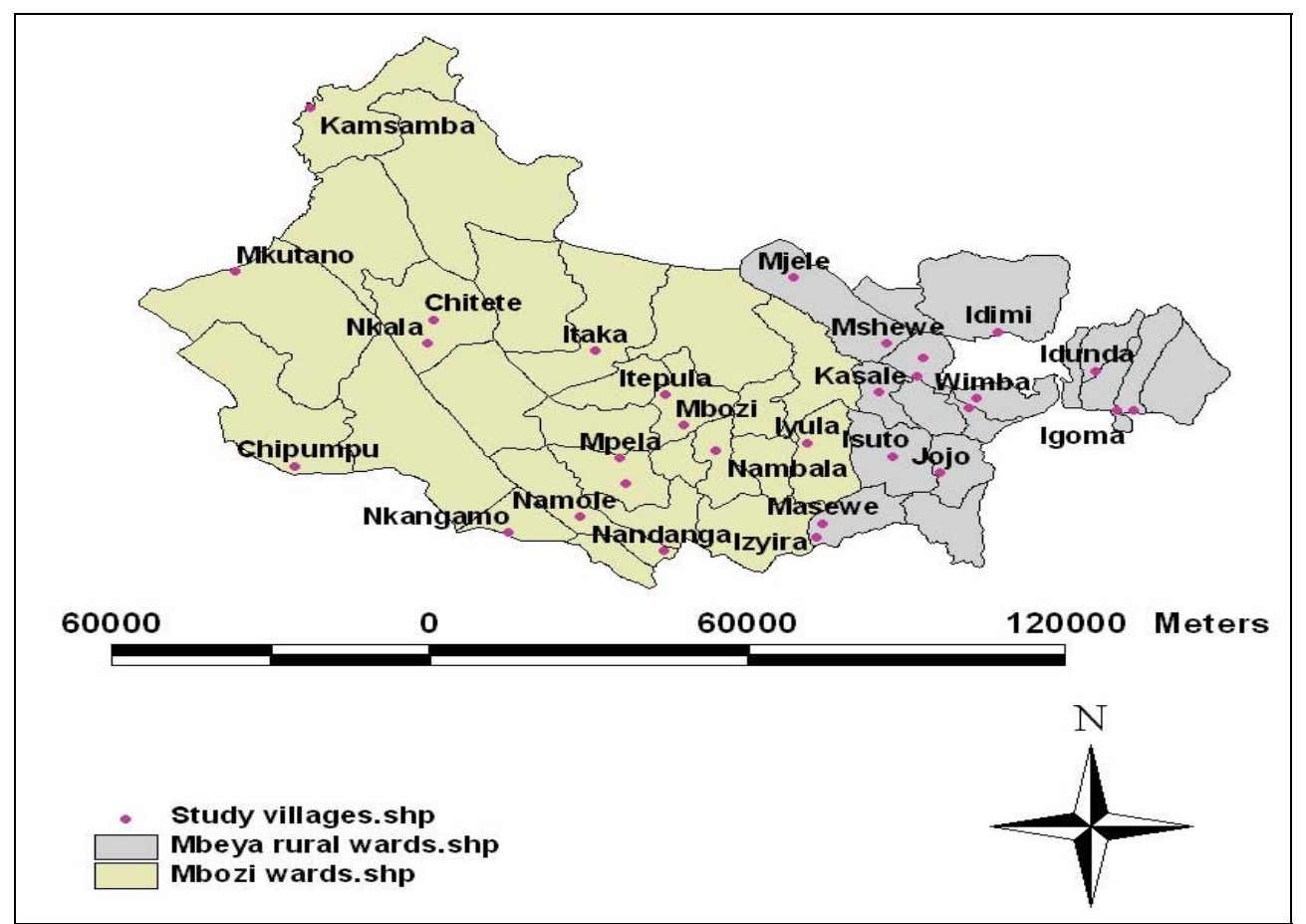

Fig. 1 Map of Mbeya rural and Mbozi districts showing wards and distribution of study villages in the cross-sectional study. 
1L: Mporoto-Umalila, 1O: Mbeya-stepped plain and 1L: Mporoto-Umalila highlands, respectively. In Mbozi district, Chitete, Nkangamo, Itaka, Namole and Iyula villages were sampled from AEZ 4F: Songwe-Msangano-Itumba trough, 4G: Tunduma-Ndalambo stretch, 1N: Mbozi plateau, 4H: Lyambalyamfipa escarpment and $1 \mathrm{~N}$ : Mbozi plateau, respectively.

PRA meetings and interviews in each targeted villages involved mainly two groups: the first group included a total of 243 pig farmers of different age and gender and the second group comprised a total of 36 key informants, such as, village leaders and other influential persons in the village. The study used PRA tools and techniques, such as, direct observations, semi-structured interviews, pair-wise matrix ranking, and historical trends [19]. Data collected include main economic activities, farming systems and importance of pig keeping in their farming system.

2.2.2 Cross-sectional Survey of Pig Keeping Households

A cross-sectional survey design using structured questionnaire was employed to collect descriptive and diagnostic data from smallholder pig keeper's households. Participating villages were randomly selected from the established sample frame for villages keeping pigs in each study district. Fifteen villages per district were randomly selected, and in each selected village, 10 pig farmers' households were randomly selected for interviews to give a total sample size of 300 households. Data collection was undertaken between November 2007 and January 2008 and involved physical visits to pig farmers' households for interviews and direct observation of household factors such as pig herd composition and shelter conditions. The data were used to describe socio-economic characteristics of pig farmers and their pig production systems and practices.

\subsection{Data Analyses}

The PRA data was analyzed manually for context and recurrent themes in the text using different levels of inductive and deductive protocols [18, 19]. Two levels of analyses, on-site and off-site were used. On-site data analysis involved PRA tools mentioned above and off-site data analysis involved harmonization (clustering) of data across the participated villages and drawing specific inferences [21].

Descriptive statistics for cross-sectional study such as means, frequency distribution, percentages and standard deviation were performed using Stata 10 software [22]. Simple linear regression was used to analyse association between variables (i.e., land and pig herd sizes). Multinomial logistic regression (MLR) analyses using Stata 10 software [22] was used to analyse relationships where categorical or discrete dependent outcome had more than two levels, such as pig production systems (total confinement (TC), semi-confinement (SC) and free range/herding (FRH)). General liner model (GLM) procedure of $\mathrm{SAS}^{\circledR}$ [23] was used to analyse univariate and multivariate analysis of variance, such as, mean number of livestock/farmer/district, mean distribution of land size, livestock number and household size in relation to different pig management systems. Least square means (LSM) were compared using probability difference of Statistical Analysis System (SAS). Means were tested using least square difference (LSD). $P$-values less than 0.05 were considered significant.

\section{Results}

\subsection{Demographic and Socio-Economic} Characteristics of Smallholder Pig Farmers

Overall, most household heads were males (85\%). Though most pig farmers $(75 \%)$ had primary education, $18 \%$ had no formal education and few possessed secondary education (7\%). The age of pig farmers' household heads ranged between 18-90 years with a mean $( \pm \mathrm{SD})$ of $41.6 \pm 13.3$ years. Mean household size was $6.0 \pm 3.1$ persons. Across the study districts, the age group between 22-55 years was 
the largest in the households (32\%) followed by age group under seven years (26\%). There were no significant differences between districts with respect to these parameters $(P>0.05)$.

Approximately $79 \%$ had engaged in pig keeping in recent years (i.e., 2000-2007), and the rest had 20 years or more years experience in pig keeping. All respondents narrated cash income from pig sale as the main reason for keeping pigs. Other reasons were manure production (49\%), slaughter for home consumption (5\%) and cultural reasons (1\%). Land size owned by pig farmers in both districts varied between 0.1 ha and 32.4 ha with a mean of $2.0 \pm 2.6$ ha/household. About $65 \%$ of households keeping pig had land size between 0.1 ha and 2 ha, whereas the rest had more than 2 ha. Pig farmers in Mbozi district had significantly more land $(2.6 \pm 0.2 \mathrm{ha})$ than their counterparts in Mbeya rural district $(1.3 \pm 0.2$ ha $)(P<$ $0.001)$.

According to the PRA study, the most important occupations of the pig farmers were crop and livestock farming. Morever, petty business, casual labour and artisan-works were also mentioned as important occupation, ranking from third to fifth, respectively. Important livestock kept were local cattle (Tanzania short horn zebu), goats, pigs and local chicken in that order. Types and mean numbers of main livestock kept by pig farmers are shown in Tables 1 and 2 .

\subsection{Pig Herd Size and Structure}

Pig herd size per household across the study districts varied between 1 and 31 pigs with mean of $4.9 \pm 4.2$ pigs. Herd size distribution varied between districts and households. Pig farmers in Mbozi district had significantly higher mean $(5.5 \pm 4.7$ pigs $)$ herd size than farmers in Mbeya rural district (4.2 \pm 3.3 pigs) $(P<0.01)$. A similar trend was also observed for herd size distribution between the two districts. About $60 \%$ of pig farmers in both districts had herd size between one and four pigs, whereas, 30.0\% had herd size between 5-10 pigs. Farmers aged between 28 years and 57 years had a significantly $(P<0.05)$ larger mean herd size than younger and older pig farmers (Table 3). Households with seven to nine individuals had a significantly larger mean herd size than those households consisting of six or less individuals $(P<0.05)$. Divorced women pig farmers had a significantly $(P<0.05)$ lower mean herd size compared to single farmers' households. Different education levels and gender of household head had no significant association with pig herd size $(P>0.05)$. Land size owned by pig farmers had significant $(P<$ $0.05, \beta=0.1)$ positive association with pig herd size.

Five pig herd structure categories were identified,

Table 1 Number (\%) of households keeping different species of livestock in addition to pigs in Mbozi $(N=151)$ and Mbeya rural $(N=149)$ districts.

\begin{tabular}{lllll}
\hline Livestock type & Mbozi number (\%) & Mbeya rural number (\%) & Total number (\%) & Chi square test $P$ value \\
\hline Local cattle & $69(46)$ & $53(36)$ & $122(41)$ & 0.074 \\
Goats & $70(46)$ & $62(42)$ & $132(44)$ & 0.41 \\
Local chicken & $137(91)$ & $93(62)$ & $230(77)$ & $<0.001 * * *$ \\
\hline
\end{tabular}

*** Significant at $P<0.001$.

Table 2 Mean number $( \pm$ SE) of main livestock species per household in Mbozi $(N=151)$ and Mbeya rural $(N=149)$ districts.

\begin{tabular}{lllll}
\hline Livestock type & Mbozi mean \pm SE & Mbeya rural mean \pm SE & Total mean & F-test $P$ value \\
\hline Pigs & $5.5 \pm 0.30$ & $4.2 \pm 0.30$ & 4.9 & $0.006^{* *}$ \\
Local cattle & $3.4 \pm 0.68$ & $1.3 \pm 0.68$ & 2.4 & $0.036^{*}$ \\
Goats & $2.1 \pm 0.32$ & $2.0 \pm 0.32$ & 2.1 & 0.81 \\
Local chickens & $8.6 \pm 0.62$ & $5.0 \pm 0.62$ & 6.8 & $<0.001^{* * *}$ \\
\hline
\end{tabular}

*Significant at $P<0.05, * *$ significant at $P<0.01$, and ***significant at $P<0.001$; SE: standard error. 
Table 3 Effect of age and household size on mean pig herd size (LSM) of the households $(N=300)$.

\begin{tabular}{llll}
\hline & Number of households & \% households & Herd size (LSM SE) \\
\hline Age groups of household head (years) & & & \\
\hline $18-27$ & 34 & 11.4 & $5.0 \pm 2.8^{\mathrm{c}}$ \\
$28-37$ & 91 & 30.5 & $7.2 \pm 1.7^{\mathrm{a}}$ \\
$38-47$ & 89 & 29.9 & $6.1 \pm 1.7^{\mathrm{ab}}$ \\
$48-57$ & 47 & 15.8 & $5.7 \pm 2.4^{\mathrm{b}}$ \\
$58-67$ & 21 & 7.0 & $3.7 \pm 3.6^{\mathrm{c}}$ \\
$68-90$ & 16 & 5.4 & $4.5 \pm 4.5^{\mathrm{c}}$ \\
\hline Household size (number of persons) & & & $4.4 \pm 0.9^{\mathrm{b}}$ \\
\hline $1-3$ & 57 & 19.0 & $4.6 \pm 0.6^{\mathrm{b}}$ \\
$4-6$ & 133 & 44.3 & $5.6 \pm 0.8^{\mathrm{a}}$ \\
$7-9$ & 82 & 27.3 & $5.1 \pm 1.3^{\mathrm{ab}}$ \\
\hline
\end{tabular}

${ }_{\mathrm{a}, \mathrm{b}, \mathrm{c}}$ Means within the same column having different superscripts are significantly different at $P<0.05$; LSM: least square means; SE: standard error.

namely, adult breeding stock, adult non-breeding stock, piglets, weaners and growers/fatteners stock. Piglets were the largest class of pigs owned by $50.0 \%$ of pig farmers with a mean number of $0.85 \pm 1.9$ for male and $0.80 \pm 1.7$ for female piglets per household, together representing $33.5 \%$ of the mean herd size. Mean age at weaning was $89.6 \pm 20.6$ d. Breeding females (sows) was the second largest proportion of the herd with a mean number of $1.0 \pm 0.9$ pigs/household, representing $20 \%$ of mean household pig herd size and the majority of pig farmers had sows (66.7\%). Mean age of sows was $22.2 \pm 9.1$ months and majority of sows (66.0\%) aged between 16 months and 30 months. Female weaners and growers represented $21.8 \%$ of mean household pig herd size with mean number of $0.52 \pm 0.89$ pigs/household and $0.55 \pm 1.10 \mathrm{pigs} /$ household, respectively. Approximately $34 \%$ and $27 \%$ of pig farmers owned female weaners and growers, respectively. Male none castrated weaners and growers represented $15.7 \%$ of mean household pig herd size with mean number of $0.5 \pm$ $1.1 \mathrm{pigs} /$ household and $0.27 \pm 0.7 \mathrm{pigs} /$ household, respectively. Castrated weaners and growers males represented $3.9 \%$ of mean household herd size with mean number of $0.05 \pm 0.34$ pigs/household and 0.14 $\pm 0.47 \mathrm{pigs} /$ household, and owned by $2.3 \%$ and $10.2 \%$ of pig keepers, respectively. Relatively few pig keeping households owned breeding boars (12.7\%). Breeding boars had lower mean age $(16.1 \pm 4.3$ months $)$ than sows. Other pig classes owned by very few households $(<5 \%)$ and with low mean numbers per household $(<0.06)$ were adult non-breeding stock (entire males and females).

\subsection{Smallholder Pig Management Systems}

Smallholder pig production systems in the study districts were classified into three management types: TC, SC and FRH. Feeding and sheltering were used as the primary classification factors. In TC systems, pigs were confined throughout the year in permanent shelters in which they were stall-fed. In SC systems, pigs were partially confined in their shelters or tethered depending on the time of a day and/or seasons of the year. Most households practising SC system had semi-permanent pig shelters. In FRH system, pigs were allowed to roam freely and/or herded during most periods of the year. These households had none or semi-permanent pig shelters.

Distribution of land, livestock and household size in the three pig management systems are summarised in Table 4. SC (49.3\%) and TC (42.0\%) were the dominant management systems, while, fewer pig farmers practiced FRH (8.7\%). Household mean land and pig herd sizes were significantly higher in households 
Table 4 Mean distribution of land, livestock, and household size in relation to different pig management systems $(N=300)$.

\begin{tabular}{lllll}
\hline & \multicolumn{3}{c}{ Mean \pm SE } \\
\cline { 2 - 5 } & TC & SC & FRH & F-test $P$ value \\
\hline Household size (no. persons) & $5.9 \pm 3.0^{\mathrm{a}}$ & $6.0 \pm 3.3^{\mathrm{a}}$ & $6.4 \pm 2.4^{\mathrm{a}}$ & $0.791 \mathrm{NS}$ \\
Land size (ha) & $1.5 \pm 2.3^{\mathrm{b}}$ & $2.3 \pm 2.9^{\mathrm{a}}$ & $2.7 \pm 2.4^{\mathrm{a}}$ & $0.019^{*}$ \\
No. pigs & $4.5 \pm 3.7^{\mathrm{b}}$ & $4.9 \pm 4.3^{\mathrm{b}}$ & $6.8 \pm 5.1^{\mathrm{a}}$ & $0.030^{*}$ \\
No. cattle & $2.4 \pm 12.1^{\mathrm{a}}$ & $2.1 \pm 3.7^{\mathrm{a}}$ & $3.7 \pm 4.7^{\mathrm{a}}$ & $0.678 \mathrm{NS}$ \\
No. goats & $1.7 \pm 2.9^{\mathrm{b}}$ & $2.1 \pm 3.9^{\mathrm{b}}$ & $4.1 \pm 6.4^{\mathrm{a}}$ & $0.012^{*}$ \\
No. chickens & $6.4 \pm 8.4^{\mathrm{b}}$ & $6.5 \pm 6.7^{\mathrm{b}}$ & $10.6 \pm 9.9^{\mathrm{a}}$ & $0.037^{*}$ \\
\hline
\end{tabular}

${ }^{\mathrm{a}, \mathrm{b}}$ Means within the same raw having different superscripts are significantly different at $P<0.05$; NS $=$ not significant $(P>0.05)$; *significant at $P<0.05$; SE: standard error.

practising FRH than those practising TC $(P<0.05)$. Likewise, mean number of goats and chickens were significantly higher for households practising $\mathrm{FRH}$ than those practising SC and TC $(P<0.05)$.

\subsection{Pig Shelters and Feeding Practices}

The majority of pig farmers had pig shelters (95.0\%). Earthen floors (44.6\%) and raised slatted wooden floors $(49.8 \%)$ were the main floor types used. A few pig farmers used concrete floor (4.6\%) and slatted wooden direct on the soil $(1.1 \%)$. The walls of most pig shelters were made of timber off cuts (50\%). While, $41 \%$ were made of tree or bamboo poles and few were made of unburned soil bricks (5.0\%) and burned soil bricks (4.0\%). About $56.0 \%$ of the shelters were roofed, and thatch grass was the most common used thatching material $(80.5 \%)$, followed by corrugated iron sheet (17\%). Only 33.0\% of pig shelters were assessed to be strong enough to keep pigs from escaping from shelters, while, $49.0 \%$ were in moderate (with minimum efforts pig may escape) and $18.0 \%$ were in poor (pig may escape at will) condition. Conditions of the respective types of pig shelters were statistically similar between Mbozi and Mbeya rural districts $(P>0.05)$.

Overall, hominy meal (high quality maize bran) was the main pig feed stuff used by $43.5 \%$ and $49.0 \%$ of farmers during the wet and dry periods, respectively. Other important feed resources were green forages, local brew wastes, sunflower seed cake, round potato tubers, banana by-products, kitchen leftovers and some fruits. None of the pig farmers used commercial pig feeds. The majority fed their pigs once daily $(67.0 \%)$, whereas, the remaining fed twice daily. However, variation existed between districts, seasons and type of management system. Feeding once daily was significantly more common during wet period $(76.0 \%)$ than during the dry period $(24.0 \%)$ and for pig farmers in Mbozi (77.7\%) than in Mbeya rural district $(22.3 \%)(P<0.05)$. Feeding twice daily was more common for farmers practicing TC than those practising SC and FRH. The amount and exact composition of ration were not assessed.

\subsection{The Effects of Different Factors on the} Distribution of Smallholder Pig Management Systems

The effects of location (districts), education level, land size, pig herd size, number of goats and cattle on the use of different pig management systems by pig farmers are summarised in Table 5. SC was significantly more common for pig farmers in Mbozi than Mbeya rural districts (odds ratio $(O R)=4.9, P<$ $0.001)$ and decreased with increasing level of education $(P<0.001)$. Pig keeping households with larger land size $(>2 \mathrm{ha})$ practised more often $\mathrm{SC}(O R$ $=1.8)$ or FRH $(O R=1.3)$ systems than pig farmers with small land size ( $\leq 2 \mathrm{ha}$ ) who practised more TC system. Number of goats and cattle per household had no significant $(P>0.05)$ influence on use of SC system. On the other hand, location (district), education level of household head, household land size, and pig herd size had varying significant effects 
Table 5 The effect of socio-economic variables of pig farmers on the frequency of different pig management systems (semi confinement (SC) and free-range/herding (FRH)) using multinomial logistic regression.

\begin{tabular}{|c|c|c|c|c|c|c|}
\hline $\begin{array}{l}\text { Management } \\
\text { system }\end{array}$ & Factors & Level of factor & No. households (\%) & $\begin{array}{l}\text { Odds ratio } \\
(O R)\end{array}$ & $95 \%$ Confidence interval & $P$ value \\
\hline \multirow{15}{*}{$\mathrm{SC}$} & \multirow{2}{*}{ District } & Mbeya rural & $54(36.2)$ & $1.0^{\mathrm{b}}$ & & \\
\hline & & Mbozi & $94(62.3)$ & 4.9 & $4.48-5.24$ & $<0.001 * * *$ \\
\hline & \multirow{3}{*}{ Education level } & Secondary & $7(33.3)$ & $1.0^{\mathrm{b}}$ & & \\
\hline & & Primary & $118(52.7)$ & 4.1 & $2.66-6.26$ & $<0.001 * * *$ \\
\hline & & No formal education & $23(41.8)$ & 2.5 & $1.73-3.50$ & $<0.001 * * *$ \\
\hline & \multirow{2}{*}{ Land size (ha) } & $\leq 2 \mathrm{ha}$ & $84(43.3)$ & $1.0^{\mathrm{b}}$ & & \\
\hline & & $>2$ ha & $63(60.6)$ & 1.8 & $1.64-1.94$ & $<0.001 * * *$ \\
\hline & \multirow{2}{*}{ No. pigs } & $1-4.9$ & $87(48.1)$ & $1.0^{\mathrm{b}}$ & & \\
\hline & & $5-31$ & $61(51.3)$ & 1.4 & $0.92-2.11$ & $0.116 \mathrm{NS}$ \\
\hline & \multirow{3}{*}{ No. goats } & None & $81(48.2)$ & $1.0^{\mathrm{b}}$ & & \\
\hline & & $1-2$ & $27(54.0)$ & 1.1 & 0.99-1.19 & $0.88 \mathrm{NS}$ \\
\hline & & $>2$ & $40(48.8)$ & 1.0 & $0.78-1.29$ & $0.988 \mathrm{NS}$ \\
\hline & \multirow{3}{*}{ No. cattles } & None & $84(47.2)$ & $1.0^{\mathrm{b}}$ & & \\
\hline & & $1-2$ & $25(55.6)$ & 1.4 & $0.41-4.83$ & $0.580 \mathrm{NS}$ \\
\hline & & $>2$ & $39(50.7)$ & 1.2 & $1.05-1.36$ & $0.009 * *$ \\
\hline \multirow{15}{*}{ FRH } & \multirow{2}{*}{ District } & Mbeya rural & $1(0.7)$ & $1.0^{\mathrm{b}}$ & & \\
\hline & & Mbozi & $25(16.6)$ & 66.5 & $64.47-68.50$ & $<0.001 * * *$ \\
\hline & \multirow{3}{*}{ Education level } & Secondary & $0(0.0)$ & $1.0^{\mathrm{b}}$ & & \\
\hline & & Primary & $23(10.3)$ & 33.0 & $24.30-62.60$ & $<0.001 * * *$ \\
\hline & & No formal education & $3(5.5)$ & 16.0 & $2.45-6.37$ & $<0.001^{* * *}$ \\
\hline & \multirow{2}{*}{ Land size (ha) } & $\leq 2 \mathrm{ha}$ & $12(6.2)$ & $1.0^{\mathrm{b}}$ & & \\
\hline & & $>2$ ha & $14(13.5)$ & 1.3 & $1.27-1.35$ & $<0.001 * * *$ \\
\hline & \multirow{2}{*}{ Pig herd size } & $1-9$ & $8(4.4)$ & $1.0^{\mathrm{b}}$ & & \\
\hline & & $5-31$ & $18(15.1)$ & 3.7 & $3.50-3.87$ & $<0.001 * * *$ \\
\hline & \multirow{3}{*}{ No. cattles } & None & $10(5.6)$ & $1.0^{\mathrm{b}}$ & & \\
\hline & & $1-2$ & $4(8.9)$ & 1.6 & $0.40-5.99$ & $0.520 \mathrm{NS}$ \\
\hline & & $>2$ & $12(15.6)$ & 1.5 & $1.05-1.36$ & $<0.001 * * *$ \\
\hline & \multirow{3}{*}{ No. goats } & None & $10(6.0)$ & $1.0^{\mathrm{b}}$ & & \\
\hline & & $1-2$ & $3(6.0)$ & 1.0 & $0.71-1.48$ & $0.898 \mathrm{NS}$ \\
\hline & & $>2$ & $13(15.9)$ & 2.5 & $2.02-3.14$ & $<0.001 * * *$ \\
\hline
\end{tabular}

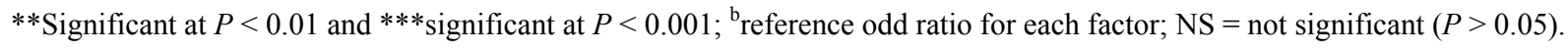

on use of FRH management system. FRH management system was significantly more practised by pig farmers in Mbozi district than in Mbeya rural district $(O R=66.6, P<0.001)$, and also significantly more common for pig farmers having primary and non-formal education than those with secondary education $(P<0.001)$.

On the other hand, pig farmers mentioned reasons which influenced them to practise different pig management systems (Fig. 2). Among important reasons for practising TC as narrated by pig farmers (multiple open responses) was the need to avoid crop damage and conflict with neighbours $(97.0 \%)$ and to avoid and or minimise diseases including porcine cysticercosis and African swine fever (42.8\%). Other reasons included improving pig security (12.7\%) and adherence to village bylaw (7.6\%). Feed supplementation, offset feeding and watering cost, periodical exercise for pigs and avoiding or minimizing conflict with neighbours were mentioned as important reasons for practising SC system. Similarly, need for feed supplementation, reducing feeding and watering cost were indicated as important reasons for practising FRH. 


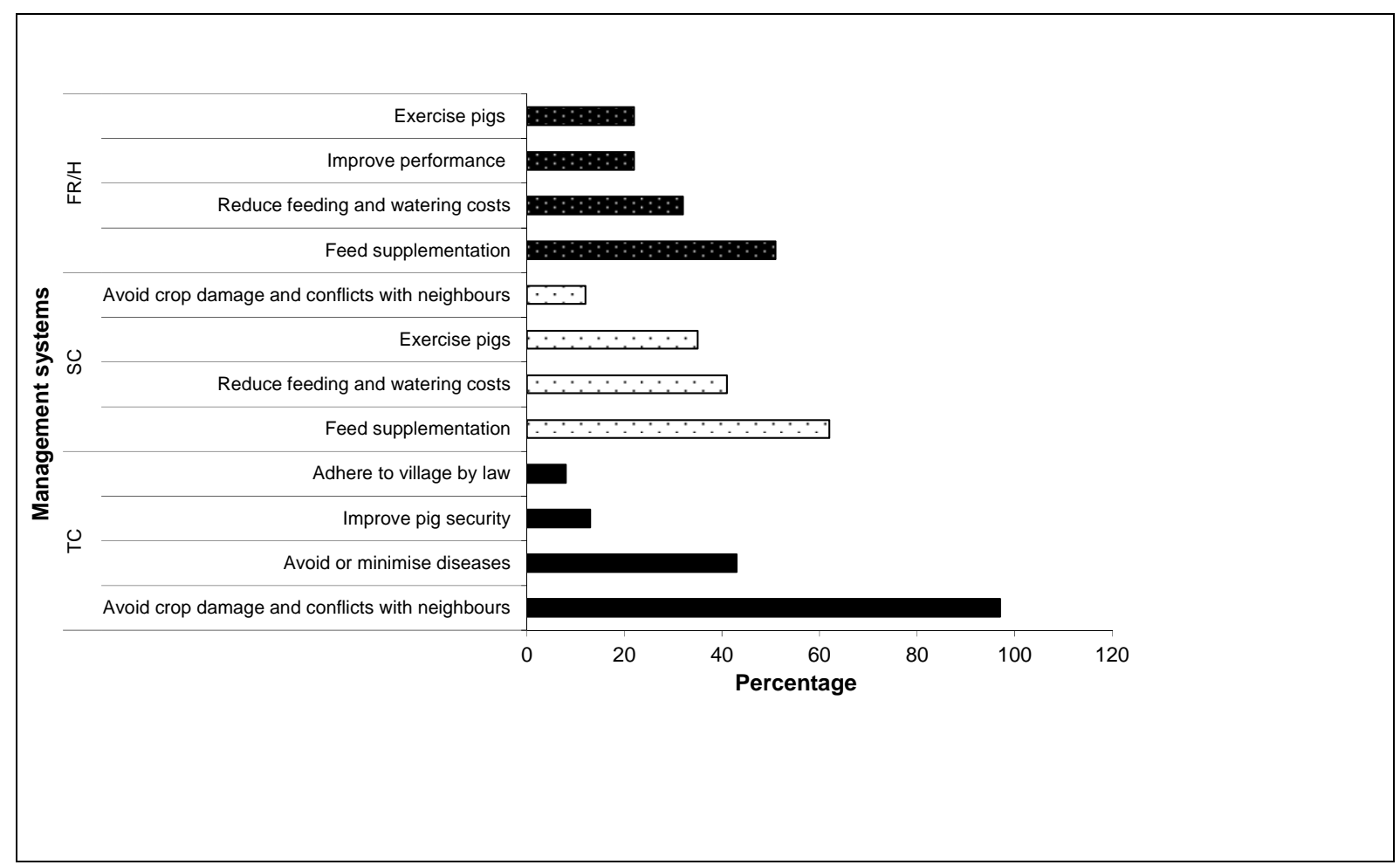

Fig. 2 Reasons for pig farmers to practise different pig management systems.

\section{Discussion}

Most pigs keeping households included married couples. Married life under village conditions in most of African countries starts early, mainly after completion of primary education [24]. The household head illiteracy level was lower compared to the general illiteracy rate $(31 \%)$ of smallholder agricultural households in Tanzania [25], overall national illiteracy rate of $27 \%$ for adults [26] and Sub-Saharan adult illiteracy level of $37 \%$ [27]. The observed literacy level of pig farmers provides potential opportunity to acquire and adopt agricultural knowledge and innovations. Education has thus been demonstrated as an important socio-economic factor enhancing the capability of farmers to adopt new agricultural innovations and consequently improving productivity [28, 29]. The observed mean age of household heads was within the active age group for carrying out effective agricultural enterprises as suggested by Tchale [30]. Age of household head and age-group distribution in the household are fundamental in smallholder household agricultural production, as they are associated with effective household labour [31]. The mean age of the households heads was, however, comparatively lower than those reported for smallholder dairy farmers [32, 33]. This observation implied that relatively young smallholder farmers were engaged in pig keeping probably due to comparatively less capital and technology needed compared to dairy production. This observation reveals potential opportunity for improving future pig productivity, if these young and energetic pig farmers will be given suitable innovations. The mean household size observed in this study was relatively higher than the mean national agricultural household size of 5.0 persons [34]. Since most smallholder agricultural production systems in the least developed countries and Tanzania in particular depend mainly on household labour, larger households provide more opportunity for labour supply [35, 36]. However, studies have shown that, the level of economic dependency and poverty increases if household size increases beyond a certain 
threshold [37-39]. According to the National Bureau of Statistics (NBS) [37], household size of seven or more individuals are two thirds more likely to be poorer than those living in households of six or less.

Mean land size owned by smallholder pig farmers (2.0 ha) in the current study, was similar to land size owned by general smallholder farmers in Tanzania which ranged between 0.9 ha and 3.0 ha [40, 41]. Land size was however lower than land size owned by smallholder dairy farmers in Gambia with a mean land size of 5.5 ha [42] and dairy farmers in Chikomba, Kadoma and Matobo districts in Zimbabwe with a mean land size of 2.8 ha [43]. Pig farmers in Mbozi had larger mean land size per household than Mbeya rural district denoting differences between these districts in terms of population density, agro-ecology and farming systems. According to NBS [17], Mbeya rural is approximately $100 \%$ more densely populated than Mbozi district. Land size has been shown to influence type, intensity and systems of livestock production [44-46]. In smallholder agricultural systems, the level of land intensification and land protection is likely to be higher in small area of land in order to maximize agricultural outputs. Pig farmers in Mbeya rural might have been operating in an agricultural system with a higher land intensification making them difficult to practise SC and FRH. SC and FRH systems were certainly more common to pig farmers in Mbozi district with more land availability and therefore room for extensive agricultural systems.

Crop farming, livestock and petty business were perceived as the most important economic activities in the farming system involving smallholder pig farmers in the current study. This scenario likely reflects the coexistence of interactions between various components (i.e., crop-crop, crop-livestock, livestock-livestock, and farm-household and farm-off farm activity components) within the system, offering means of sustaining the pig farmer's livelihood. However, interactions may result in trade-offs, compromises, or competition while meeting the multiple objectives of the pig farmers households. Nevertheless, different studies have shown the importance of integrated systems especially mixed crop-livestock system in the livelihood of smallholder farmers and as the backbone of agricultural development in developing world [47, 48]. Similarly, other species of livestock such as cattle, goats and chickens in addition to the pigs revealed more evidence of sub-system "livestock-livestock interaction", which is a very important element in mixed crop-livestock systems. These systems provide opportunities to access important resources for pig production such as feeds, thus increasing potential for enhancing smallholder pig productivity.

Herd size across the two study districts suggest that pig production is based on small holding operations with herd sizes corresponding with household resource endowment such as land, labour and capital. Mean household herd size was noted to be influenced by various pig farmers' socio-economic factors. Higher mean herd size for pig farmers aged 28-57 years might be caused by the fact that this age group comprises energetic pig farmers with comparatively high economic status in the community $[25,49]$ and willingness to take risk $[50,51]$. Mean herd size was low in divorced headed households, which might be caused by a low socio-economic base of these households. Most of divorcees were women (most divorced men usually re-married). And according to prevailing traditions, divorced women loose most of the important production assets such as land and capital, which are important components for successful pig production. In this situation, such households were only able to keep small pig herd that could be manageable within their marginal socio-economic situation. Land size apparent had a positive influence on pig herd size, in that herd size increased with increased land size. Land is one of the most important resources and assets in smallholder production system [43, 44, 52]. Studies have thus 
shown a positive relationship between land size and household wealth $[44,52,53]$. Based on this scenario, households with large land size in the current study were also more likely to possess a larger socio-economic base such as capital and labour, which are important investment components in pig production.

Besides mean pig herd size being small, smallholder pig farmers kept strategically different pig herd structure based on their objectives and socio-economic circumstances. The majority of pig farmers kept breeding stock, which may have been more attractive than fattening in relation to investment requirement and return on investment. This observation was similar to findings from smallholder pig production system in central Kenya [54], Ramotwa village in Botswana [55] and Dhemaji district in India [56], where breeding females were kept by majority of pig farmers. The proportion of households keeping breeding boars and the mean number of breeding boars per household was small in the current study. This might be a strategy to reduce production cost. To offset the scarcity, sharing a boar between multiple farms has been very common to pig farmers. However, moving boars between multiple farms posed a major biosecurity problem and secondly contributed to pig inbreeding.

Level of education was identified as important factors influencing pig farmers to practise different management systems. Pig farmers with secondary and primary education were more often practising TC than farmers with no formal education. This observation suggests that education may also influence adoption of TC systems, e.g., more educated pig farmers were better able to handle the risks associated with adoption of TC system and perhaps better informed about advantages and requirements of management system. Studies have also reported the effects of education on utilization of improved agricultural innovations and advocate provision of education packages as key component in smallholder farmer's adoption of new agricultural practises $[28,30,57,58]$.

It was also observed that pig farmers with large pig herd sizes practised FRH more often than pig farmers with small herd sizes. Pig herd size has an association with resources investment such as feeds, shelter and labour. The larger the herd size is, the higher is the demand for resources and thus the higher investment costs. In this situation, pig farmers with large herd sizes may have used FRH management systems as a strategy to reduce investment costs, as supported by statement by pig farmers that reduced feeding cost was the main reason for practising FRH.

Presence and condition of pig shelters are important aspects in biosecurity of pigs [59]. The predominance of poorly made earthen and slatted floor with limited comfort to pigs and it could allow escape of pigs from their shelters was probably an indication of inadequate knowledge on appropriate shelters for pigs. Lack of resources or other socio-economic circumstances and poor perception on the need of pig shelters may have also contributed to the outcome. It was evident that poor quality shelters were also found on farms supposedly practicing TC, indicating that confinement was not fully practiced. This finding agrees with those reported by Phiri et al. [13] in ESA region and Kagira et al. [50] in Kenya, where pigs were kept in primitive structures especially in areas where extensive pig keeping were dominant.

Pig farmers used mostly locally available feed stuffs and feeding strategies to reduce feed costs. The use of local feedstuffs may have also caused by poor availability of commercial feeds and associated costs. This observation agrees with findings in Tanzania [60], in Kenya [54], Nigeria [51, 61] and in tropical resource poor communities [62], where cheap locally available feed resources were used as the main feed resource base for pigs. However, based on feed types, amount and feeding regimes, this study indicate inadequate feeding, which is likely to have resulted in poor productive and reproductive performances of pigs. 


\section{Conclusions}

Smallholders pig production systems are invariably small-scale enterprises practised by pig farmers using different pig management systems. Three pig management systems practised by pig farmers, namely, total confinement; partial confinement and free range were identified. The adoption of one type of a system depended on a number of factors including age and literacy level of a farmer, land size, crop-livestock interaction and availability of feed and water resources. Other factors, such as, prevailing agricultural sub systems, locally available resources like pig feeds and building materials for pig shelter, influence the pig management systems. For sustainable improvement of smallholder pig production systems, it is recommended to carefully consider the prevailing agricultural farming systems, locally available resources for pig production and socio-economic circumstances of pig farmers.

\section{Acknowledgments}

This study was funded by the Danish International Development Agency (DANIDA) through the Cross-disciplinary Risk Assessment of Porcine cysticercosis in ESA project, and their support is highly valued and appreciated. The authors are indebted to pig farmers in the study villages for their willingness to share their experiences with us.

\section{References}

[1] Bureau of Public Affairs (BPA). 2009. "Background Note of Tanzania." United States America, Department of State. Accessed August 8, 2010. http://www.state.gov/r/pa/ei/bgn/2843.htm.

[2] Food and Agriculture Organization of the United Nations (FAO). 2005. Livestock Information Sector Analysis and Policy Branch. Tanzania Livestock Sector Brief Report, AGAL, FAO. Accessed January 10, 2010. http://www.faostat.external.fao.org/default.jsp.

[3] The United Republic of Tanzania (URT). 2012. National Sample Census of Agriculture, Smallholder Agriculture 2007/2008. National Report Volume III: Livestock Sector, the National Bureau of Statistics and the Office of the Chief Government Statistician, Zanzibar.
[4] Food and Agriculture Organization of the United Nations (FAO). 2012. FAO Statistical Databases. Accessed October 25, 2012. http://faostat3.fao.org/home/index.html.

[5] Waiswa, C. S., Fèvre, E. M., Nsadha, Z., Sikasuge, C. S., and Willingham, A. L. 2009. "Porcine Cysticercosis in Southeast Uganda: Seroprevalence in Kamuli and Kaliro Districts." Journal of Parasitology Research. Accessed June 28, 2014. http://www.hindawi.com/journals/jpr/2009/375493/.

[6] Mutua, F., Arimi, S., Ogara, W., Dewey, C., and Schelling, E. 2010. "Farmer Perceptions on Indigenous Pig Farming in Kakamega District, Western Kenya." Nord. J. Afr. Stud. 19 (1): 43-57.

[7] Food and Agriculture Organization of the United Nations (FAO). 2012. "Pig Sector Kenya." FAO Animal Production and Health Livestock Country Reviews No. 3, FAO, Rome. Accessed November 10, 2012. http://www.fao.org/docrep/015/i2566e/i2566e00.pdf.

[8] Delgado, C. L., Rosegrant, M., Steinfeld, H., Ehui, S., and Courbois, C. 1999. "Livestock to 2020: The Next Food Revolution." Food, Agriculture and the Environment Discussion Paper 28, IFPRI, FAO and ILRI. Accessed September 12, 2014. http://www.animalbiotechnology.org/livestock\%20revolu tion.pdf.

[9] Psilos, P. 2008. "Swine Marketing in Cambodia: Reducing Market Distortions, Improving Competitiveness and Ensuring Safe Trade." USAID, FAO, EU and SLPP. Accessed January 18, 2013. http://www.aphca.org/publications/files/Swine Marketing in Cambodia FAO-USAID-EU-Final.pdf.

[10] Lemke, U., and Valle-Zarate, A. 2008. "Dynamics and Developmental Trends of Smallholder Pig Production Systems in Northern Vietnam: Pig Production Management and Pig Performances." Livest. Sci. 105: 229-43.

[11] Kumaresan, A., Bujarbaruah, K. M., Pathak, K. A., Das, A., and Bardoloi, R. K. 2009. "Integrated Resource-Driven Pig Production Systems in a Mountainous Area of Northeast India: Production Practices and Pig Performance." Trop. Anim. Health Prod. 41 (7): 1187-96.

[12] Riedel, S., Schiborra, A., Huelsebusch, C., Huanming, M., and Schlecht, E. 2012. "Opportunities and Challenges for Smallholder Pig Production Systems in a Mountainous Region of Xishuangbanna, Yunnan Province, China.” $J$. Trop. Anim. Health Prod. 44 (8): 1971-80.

[13] Phiri, I. K., Ngowi, H., Afonso, S., Matenga, E., Boa, M., Mukaratirwa, S., Githigia, S., Saimo, M., Sikasunge, C., Maingi, N., Lubega, G. W., Kassuku, A., Michael, L., Siziya, S., Krecek, R. C., Noormahomed, E., Vilhena, M., 
Dorny, P., and Willingham, A. L. 2003. "The Emergence of Taenia solium Cysticercosis in Eastern and Southern Africa as a Serious Agricultural Problem and Public Health Risk." Acta Trop. 87 (1): 13-23.

[14] Kagira, J. M., Maingi, N., Kanyari, P. W. N., Githigia, S. M., Ng'ang'a, J. C., and Gachohi, J. M. 2010. "Characteristics of Pig Trade in Low Income Settings in Busia District, Kenya." Tanzan. Vet. J. 27 (1): 26-35.

[15] Mutua, F. K., Dewey, C. E., Arimi1, S. M., Schelling, E., Ogara1, W. O., and Levy, M. 2011. "Reproductive Performance of Sows in Rural Communities of Busia and Kakamega Districts, Western Kenya." Afr. J. Agric. Res. 6 (31): 6485-91.

[16] Cheng, H., Wang, Y., Meng, Q., Guo, J., and Wang, Y. 2011. "Pork Production System and Its Development in Mainland China." Int. J. Fish. Aquac. 3 (5): 166-74.

[17] National Bureau of Statistics (NBS). 2013. 2012 Population and Housing Census. General Report. Accessed October 10, 2013. http://www.nbs.go.tz/sensa/new.html.

[18] Matata, J. B. 2001. Farming Systems Approach to Technology Development and Transfer: A Source Book. Harare, Zimbabwe: FARMESA Publisher, 275.

[19] Kirway, T. N., Lema, N. M., Lyimo, S. D., Kileo, R. O., Kapange, B. W., Schouten, C., and Strader, T. 2003. Farming Systems Approaches Training Manual. Vol. 1. Dar es Salaam, Tanzania: Ministry of Agriculture and Food Security, 212.

[20] Mussei, A. N., Mbwile, R. P., Kamasho, J. K., Mayona, C. M., Ley, G. J., and Mghogho, R. M. 1999. Agro-Ecological Zones and Farming Systems of the Southern Highlands of Tanzania. Mbeya, Tanzania: Ministry of Agriculture and Cooperative, Southern Highlands Zonal Agricultural Research Institute, 49.

[21] Pretty, J. N., Guijt, I., Thompson, J., and Scoones, I. 1995. A Trainer Guide for Participatory Learning and Action. London: IIED, 213.

[22] Stata Corp. 2007. Stata: Data Analysis and Statistical Software (Release 10). TX, USA: Stata Corp LP, College Station, 147.

[23] Statistical Analysis System (SAS). 2000. SAS/STAT ${ }^{\circledR}$ Version 8.1. Users Guide. SAS Institute, Cary, NC, USA. Accessed September 25, 2010. http://v8doc.sas.com/sashtml/stat/chap30.htm.

[24] National Bureau of Statistics (NBS). 2009. Household Budget Survey 2007. Ministry of Finance and Economic Affairs and National Bureau of Statistics Final Report, Dar es Salaam, Tanzania.

[25] The United Republic of Tanzania (URT). 2005. National Strategy for Growth and Reduction of Poverty (NSGRP). Dar-es-Salaam: Vice President's Office, 102.

[26] United Republic of Tanzania (URT). 2013. "Tanzania in
Figures 2012.” National Bureau of Statistics and Ministry of Finance. Accessed November 10, 2013. http://www.nbs.go.tz/takwimu/references/Tanzania_in_fi gures2012.pdf.

[27] United Nations Educational, Scientific and Cultural Organization (UNESCO). 2012. "Adult and Youth Literacy." UNESCO Institute for Statistics (UIS) Fact Sheet No. 20. Accessed April 24, 2014. http://www.uis.unesco.org/literacy/Documents/fs20-litera cy-day-2012-en-v3.pdf.

[28] Alene, A. D., and Manyong, V. M. 2007. "The Effects of Education on Agricultural Productivity under Traditional and Improved Technology in Northern Nigeria: An Endogenous Switching Regression Analysis." Empir. Econ. 32 (1): 141-59.

[29] Olaleye, R. S., Gana, F. S., Umar, I. S., Ndanisa, M. A., and Peter, E. W. 2009. "Effectiveness of Radio in the Dissemination of Agricultural Information among Farmers in Edu Local Government Area of Kwara State, Nigeria." Cont. J. Agric. Sci. 3: 1-6.

[30] Tchale, H. 2009. "The Efficiency of Smallholder Agriculture in Malawi." Afr. J. Agr. Resour. Econ. 3 (2): 101-21.

[31] Anim, F. D. K. 2011. "Factors Affecting Rural Household Farm Labour Supply in Farming Communities of South Africa." J. Hum. Ecol. 34 (1): 23-8.

[32] Mollel, E. L., Lekule, F. P., Kurwijila, R. L., Turuka, F. M., and Petersen, P. H. 1999. "A Socio-Economic Study on the Role of Gender in Small Scale Crop-Livestock Farming in Turiani Division, Morogoro." In Proceedings of the 26th Scientific Conference of the Tanzania Society of Animal Production, 121-7.

[33] Njarui, D. M. G., Kabirizi, J. M., Itabari, J. K., Gatheru, M., Nakiganda, A., and Mugerwa, S. 2012. "Production Characteristics and Gender Roles in Dairy Farming in Peri-Urban Areas of Eastern and Central Africa." Livest. Res. Rural Dev. 24: 122.

[34] United Republic of Tanzania (URT). 2006. National Sample Census of Agriculture 2002/2003, Smallholder Agriculture. National Report Volume III: Livestock Sector. National Bureau of Statistics, Ministry of Agriculture and Food Security, Ministry of Water and Livestock Development, Ministry of Cooperatives and Marketing, President Office, Regional Administrative and Local Government, Ministry of Finance and Economic Affairs, Zanzibar.

[35] The United Republic Of Tanzania (URT). 2000. Poverty Reduction Strategy Paper (PRSP). Dar es Salaam, Tanzania: Tanzania Government Publishing, 53.

[36] Jera, R., and Ajayi, O. C. 2008. "Logistic Modelling of Smallholder Livestock Farmers' Adoption of Tree-Based Fodder Technology in Zimbabwe." Agr. Econ. Res. 47 (3): 379-92. 
[37] National Bureau of Statistics (NBS). 1993. Household Budget Survey 1991/92. National Bureau of Statistics, Final Report, Dar es Salaam, Tanzania.

[38] National Bureau of Statistics (NBS). 2002. Household Budget Survey 2000/01. Final Report, Dar es Salaam, Tanzania.

[39] Aniceto, O. J. 2005. "Poverty, Vulnerability and Family Size: Evidence from the Philippines." Discussion Papers DP 2005-19, Philippine Institute for Development Studies. Accessed January 15, 2015. http://serp-p.pids.gov.ph/details.php?pid=3723\&param $=$ v ulnerability.

[40] Participatory Agricultural Development and Empowerment Project (PADEP). 2003. "Environmental, Social and Resettlement Frameworks." Ministry of Agriculture and Food Security. Accessed December 17, 2011. http://www.tanzania.go.tz/agriculture.html.

[41] Sarris, A., Savastano, S., and Christiaensen, L. 2006. "The Role of Agriculture in Reducing Poverty in Tanzania: A Household Perspective from Rural Kilimanjaro and Ruvuma." FAO Commodity and Trade Policy Research Working Paper No. 19, FAO, Rome, Italy. Accessed October 11, 2014. http://www.fao.org/3/a-ah468e.pdf.

[42] Somda, J., Kamuanga, M., Münstermann, S., and Bittaye, A. 2003. "Socio-Economic Characterization of Smallholder Dairy Systems in the Gambia: Milk Production, Marketing and Consumption." Socio-Economic Research Working Paper No. 1, International Trypanotolerance Centre, Banjul, Gambia. Accessed June 17, 2014. http://www.itc.gm/Downloads/soceconresworkingpapern ol.pdf.

[43] Chawatama, S., Mutisi, C., and Mupawaenda, A. C. 2005. "The Socio-Economic Status of Smallholder Livestock Production in Zimbabwe: A Diagnostic Study." Livest. Res. Rural Dev. Vol. 17, No. 12. Accessed June 28, 2014. http://www.lrrd.org/lrrd17/12/chaw17143.htm.

[44] International Livestock Research Institute (ILRI). 1995. Major Livestock Production Systems in Africa. Livestock Policy Analysis, ILRI Training Manual 2, ILRI, Nairobi, Kenya.

[45] Sere, C., and Steinfeld, H. 1996. "World Livestock Production Systems: Current Status, Issues and Trends." FAO Animal Production and Health Paper 127, Food and Agriculture Organization, Rome. Accessed August 10, 2012. ftp://ftp.fao.org/docrep/fao/005/w0027e/w0027e00.pdf.

[46] Rao, P., and Birthal, P. S. 2002. "Strategic Assessments and Development Pathways for Agriculture in the Semi-Arid Tropics." Policy Brief No. 1, ICRISAT, Andhra Pradesh, India. Accessed January 12, 2013. http://www.icrisat.org/what-we-do/mip/resources/policy-
briefs/Pb1.pdf.

[47] Sulc, R. M., and Tracy, B. F. 2007. "Integrated Crop-Livestock Systems in the U.S. Corn Belt." American Soc. of Agon. J. 99: 335-45.

[48] Franzluebbers, A. J. 2007. "Integrated Crop-Livestock Systems in the Southeastern USA." American Soc. of Agon. J. 99: 361-72.

[49] Lien, G., Kumbhakar, S. C., and Hardaker, J. B. 2008. "Determinants of Part-Time Farming and Its Effect on Farm Productivity and Efficiency." Presented at the 107th EAAE Seminar on Modelling of Agricultural and Rural Development Policies, Sevilla, Spain.

[50] Kagira, J. M., Kanyari, P. W. N., Maingi, N., Githigia, S. M., Ng'ang'a, J. C., and Karuga, J. W. 2009. "Characteristics of the Smallholder Free-Range Pig Production System in Western Kenya." J. Trop. Anim. Health Prod. 35: 79-84.

[51] Ajala, M. K., Adesehinwa, A. O. K., and Mohammed, A. K. 2007. "Characteristics of Smallholder Pig Production in Southern Kaduna Area of Kaduna State, Nigeria." Am. Eurasian J. Agric. Environ. Sci. 2: 182-7.

[52] New Partnership for Africa's Development (NEPAD). 2006. Companion Document to CAADP: Integrating Livestock, Forestry and Fisheries Subsectors into the $C A A D P$. Comprehensive Africa Agriculture Development Programme, FAO.

[53] Blank, S. C., Erickson, K. W., Nehring, R., and Hallahan, C. 2009. "Agricultural Profits and Farm Household Wealth: A Farm-Level Analysis Using Repeated Cross Sections." J. Agri. Appl. Econ. 41 (1): 207-25.

[54] Wabacha, J. K., Maribei, J. M., Mulei, C. M., Kyule, M. N., Zessin, K. H., and Oluoch-Kosura, W. 2004. "Health and Production Measures for Smallholder Pig Production in Kikuyu Division, Central Kenya." Prev. Vet. Med. 63: 197-210.

[55] Nsoso, S. J., Mannathoko, G. G., and Modise, K. 2006. "Monitoring Production, Health and Marketing of Indigenous Tswana Pigs in Ramotswa Village of Botswana." Livest. Res. Rural Dev. Vol. 18, No. 125. Accessed April 6, 2015. http://www.lrrd.org/lrrd18/9/nsos18125.htm.

[56] Deka, R., Thorpe, W., Lapar, M. L., and Kumar, A. 2007. Demaji's Pig Sub-Sector: Current Status, Constraints and Opportunities. Project Report, International Livestock Research Institute, Nairobi, Kenya.

[57] Appleton, S., and Balihuta, A. 1998. "Education and Agricultural Productivity: Evidence from Uganda." J. Int. Dev. 8 (3): 415-44.

[58] Reimers, M., and Klasen, S. 2011. Revisiting the Role of Education for Agricultural Productivity. Discussion Papers, Ibero America Institute for Economic Research No. 214. 
[59] Food and Agriculture Organization of the United Nations (FAO). 2010. "Good Practices for Biosecurity in the Pig Sector-Issues and Options in Developing and Transition Countries." FAO Animal Production and Health Paper No. 169, Rome, FAO. Accessed May 12, 2012. http://www.fao.org/docrep/012/i1435e/i1435e00.pdf.

[60] Kimbi, E. C., Kaijage, J. T., and Maiseli, N. G. 2003. "Local Feed Resource Base, Feeding Systems and Practices for Smallholder Pig Production in the Southern Highlands of Tanzania: A Case Study of Mbeya Region." In Proceedings of the 30th Scientific Conference of the
Tanzania Society of Animal Production, 120-37.

[61] Ironkwe, M. O., and Amefule, K. U. 2008. "Appraisal of Indigenous Pig Production and Management Practices in Rivers State, Nigeria.” J. Agri. Socio. Res. Vol. 8, No. 1. Accessed December, 2014. http://www.ajol.info/index.php/jasr/article/download/287 8/32179.

[62] Lekule, F. P., and Kyvsgaard, N. C. 2003. "Improving Pig Husbandry in Tropical Resource-Poor Communities and Its Potential to Reduce Porcine Cysticercosis." Acta Trop. 87 (1): 112-7. 